\title{
The box office performance of European films in the UK
}

Huw David Jones

University of York, UK

\begin{abstract}
European films accounted for $17.4 \%$ of UK cinema releases in the period $2002-14$, but only $1.8 \%$ of the gross box office. Drawing on box office data, audience surveys and interviews with industry players, this article argues that European films generally perform badly in the UK box office because they suffer from a heavy 'cultural discount' and structural weaknesses at the level of production and distribution. Those European films which do 'breakout' are either English-language films with qualities designed to appeal to a mainstream British audience (e.g. stars and special effects) or foreign language films with cultural elements (e.g. well-known story, director, genre, subject matter or source material) which many British cinemagoers are already familiar with. Breakout European films are also mainly released by Hollywood studios or major independent distributors. These findings provide insights into academic and policy debates about the transnational circulation of film and other media products.
\end{abstract}




\section{Introduction}

Britain's historic decision to leave the European Union (EU) in the referendum on 23 June 2016 took many political commentators, pollsters and members of the public by surprise. Yet if we see engagement with European film as a broader indicator of proEuropean sentiment, then perhaps the result is less surprising. ${ }^{1}$ According to the UK Film Council (UKFC)/British Film Institute's (BFI) Statistical Yearbooks (2003-14), European films averaged $17.4 \%$ of UK cinema releases in the period 2002-14, but accounted for only $1.8 \%$ of the gross box office (figure 1) - the lowest market share for European films in the EU28 (MEDIA Salles 2012). Excluding English-language films, the proportion falls to just $1.1 \%$ - or about 1.8 million admissions per year. That is about half what Skyfall (Mendes, UK/USA, 2012), the top-selling film of 2012, took solely in its opening weekend (BFI 2013, 24).

[Figure 1 here]

The pattern is much the same outside the theatrical market. A European Commission (2014) survey, for example, found that only $5 \%$ of Britons frequently watched European films on any media platform, compared with an EU average of $14 \%$.

Nevertheless, some European titles are well-received in the UK. Between 2007 and 2013, there were 34 European films which took $£ 1$ million or more at the UK box office (about 200,000 admissions) - the industry's benchmark for a 'breakout' title (table 1). Nearly half were foreign-language productions, including The Lives of Others (von Donnersmarck, Germany, 2006), La Vie En Rose (Dahan, France/Czech Republic/UK, 2007), The Girl with the Dragon Tattoo (Oplev, Sweden/Denmark/Germany, 2009) and Broken Embraces (Almodóvar, Spain, 2009). 
Meanwhile, the UK has seen an unprecedented growth in the popularity of European

television dramas in recent years. Scandinavian crime series such as The Killing and

The Bridge have become regular fixtures on BBC Four's Saturday night schedule,

frequently pulling in over 1 million viewers. On Channel 4, 1.9 million watched the

French-language supernatural thriller The Returned in June 2013, while over 2 million

saw the German-language spy drama Deutschland ' 83 in January 2016, a record for a

foreign-language television series. Even the commercial satellite station Sky is getting

in on the action with The Tunnel, an Anglo-French remake of The Bridge, and the

Danish family drama, The Legacy.

\begin{tabular}{|c|c|c|c|c|c|c|c|c|}
\hline & Film & Year & Lang. & Country & Genre & Directors & UK distributor & UK admissions \\
\hline 1 & Taken 2 & 2012 & EN & FR & Action / Crime / Thriller & Olivier Megaton & 20TH CENT. FOX & $3,692,417$ \\
\hline 2 & The Impossible & 2013 & EN & ES & Drama / Thriller & Juan Antonio Bayona & eONE & $2,037,493$ \\
\hline 4 & Taken & 2008 & EN & FR / US / GB & Action / Crime / Thriller & Pierre Morel & 20TH CENT. FOX & $1,232,830$ \\
\hline 5 & Arthur and the Invisibles & 2007 & FR & FR & Animation / Adventure / Family & Luc Besson & MOMENTUM & $1,090,792$ \\
\hline 6 & Planet 51 & 2009 & EN & $\mathrm{ES} / \mathrm{GB}$ & Animation / Comedy / Animation & Javier Abad / Jorge Blanco & ENTERTAINMENT & 916,506 \\
\hline 10 & The Three Musketeers & 2011 & EN & $\mathrm{DE} / \mathrm{GB} / \mathrm{FR}$ & Action / Adventure / Romance & Paul W.S. Anderson & eONE & 573,764 \\
\hline 11 & A Monster in Paris & 2012 & FR & FR & Animation / Adventure / Comedy & Bibo Bergeron & eONE & 534,717 \\
\hline 12 & The Lives of Others & 2007 & $\mathrm{DE}$ & $\mathrm{DE}$ & Drama / Thriller & Florian Henckel von Donnersmarck & LIONSGATE & 534,610 \\
\hline 13 & Transporter 3 & 2008 & EN & FR / GB & Action / Adventure / Crime & Olivier Megaton & ICON & 496,334 \\
\hline 14. & Justin and the Knights of Valour & 2013 & EN & ES & Animation / Adventure / Family & Manuel Sicilia & eONE & 495,054 \\
\hline 15 & Coco Before Chanel & 2009 & FR & FR & Biography / Drama & Anne Fontaine & OPTIMUM & 482,884 \\
\hline 21 & The Intouchables & 2012 & FR & FR & Biography / Comedy / Drama & Olivier Nakache / Eric Toledano & ENTERTAINMENT & 319,556 \\
\hline 22 & From Paris with Love & 2010 & EN & FR & Action / Crime / Thriller & Pierre Morel & WARNER BROS. & 309,557 \\
\hline 23 & Resident Evil: Retribution & 2012 & EN & DE / CA / US & Action / Horror & Paul W.S. Anderson & SONY PICTURES & 292,751 \\
\hline 24 & Silent Hill: Revelation 3D & 2012 & EN & FR / US & Horror / Mystery / Thriller & Michael J. Bassett & LIONSGATE & 290,295 \\
\hline 25 & The Girl who Played with Fire & 2010 & SV & SE / DK / DE & Crime / Drama / Mystery & Daniel Alfredson & MOMENTUM & 279,038 \\
\hline 26 & Sammy's Adventures 2 & 2013 & EN & $\mathrm{BE} / \mathrm{FR} / \mathrm{IT}$ & Animation / Adventure / Family & Vincent Kesteloot, Ben Stassen & WARNER BROS. & 270,833 \\
\hline 27 & Cloud Atlas & 2013 & EN & DE / US & Drama / Sci-fi & Tom Tykwer, Andy Wachowski & WARNER BROS. & 256,746 \\
\hline 28 & Broken Embraces & 2009 & ES & ES & Drama / Romance / Thriller & Pedro Almodóvar & PATHE & 250,642 \\
\hline 29 & The Skin I Live In & 2011 & ES & ES & Drama / Horror / Thriller & Pedro Almodóvar & PATHE & 248,487 \\
\hline 30 & I've Love You So Long & 2008 & FR & $F R / D E$ & Drama & Philippe Claudel & LIONSGATE & 236,025 \\
\hline 31 & Tell No One & 2007 & FR & FR & Crime / Drama / Mystery & Guillaume Canet & REVOLVER & 235,720 \\
\hline 32 & Babylon A.D. & 2008 & EN & FR / US & Action / Adventure / Sci-Fi & Mathieu Kassovitz & 20TH CENT. FOX & 226,316 \\
\hline 33 & Head Hunters & 2012 & NO & NO/ DE & Crime / Thriller & Morten Tyldum & MOMENTUM & 225,837 \\
\hline
\end{tabular}

Table 1. 'Breakout' European films with 200,000 admissions or more at the UK box office, 2007-2013. Sources: BFI / LUMIERE / IMDb.

This article examines two key questions: (1) why is the UK market for European

film so small; and (2) how do certain European films achieve 'breakout' success? To 
answer these questions, I examine the production, content, distribution and reception of European films in the UK. I draw in particular on box office data and audience surveys produced by agencies like the BFI and the European Audiovisual Observatory (EAO). This quantitative approach allows me to identify broad patterns, trends and variations within the UK film market, which studies focusing on the reception of specific European titles may overlook. To help understand these industry trends, I have also conducted a number of interviews with UK distributors, exhibitors and policymakers who specialise in European film. ${ }^{2}$

The article aims to contributes to wider academic debates about transnational media flow - that is to say, why some films travel better than others. Is it primarily due to the cultural content of the films themselves (e.g. the language, characters or genre)? Or is it because of the industrial structures which support their production, distribution and exhibition? My argument is that while cultural factors go a long way to explaining why so few British people engage with European films (especially non-English language productions), there are also important industrial issues at play, such as the loss of specialised screen space, market saturation or increasing distribution costs. Moreover, while 'break out' European films generally have cultural elements which British audiences can more easily identify with (e.g. well-known actors, recognisable subject matter or familiar source material), they also tend to be distributed by Hollywood studios or major independent distributors, rather than smaller independents. In other words, their success is due to a combination of cultural and industrial factors. Although my focus is on feature films, these findings clearly have implications for European television drama and other imported media products.

\section{Why the UK market for European film is so small}


One influential theory which helps explain why the UK market for European film is so small is Hoskins and Mirus's (1988) notion of 'cultural discount'. This is the idea that media products rooted in one culture 'will have a diminished appeal elsewhere as viewers find it difficult to identify with the style, values, beliefs, institutions, and behavioural patterns of the material in question' (Hoskins and Mirus 1988, 500). Thus a film from the US is likely to perform better in the UK than one from, say, China or Japan, because of Britain and America's closer cultural proximity in terms of language, customs and traditions (see also Straubhaar 2003). Hoskins and Mirus add that where two countries face the same level of cultural discount, the one with the largest domestic market will dominate international trade - a phenomenon they call the 'home market effect'. This is because countries with a large home market generate more domestic revenue to invest in the elements (e.g. stars, production values and marketing) which make media products appealing to overseas audiences.

While there has been no research on how 'cultural discount' affects the UK market for European films, there is certainly empirical evidence to support the theory in other geographical contexts. Lee (2006, 2008), for example, shows that US action and sci-fi movies tend to perform better in the Asian market than more culturally-specific genres like comedies. Similarly, Lee and Waterman (2007) suggest the reason why the US has increased its share of global film trade since the 1950s is because its home market has grown at a faster rate than the UK, France, Germany, Italy or Japan.

However, the 'cultural discount' theory has also attracted critics. From a 'critical political-economic' perspective, Miller et al. (2005, 4), for example, suggest that Hoskins and Mirus's 'neoclassical economic conservativism' ignores the role of the US government in terms of regulating the global film trade in Hollywood's favour. In other words, the reason why the US has come to dominate global film trade has less to do 
with the fact that its films suffer a lower cultural discount than its competitors and more because of Hollywood studios have been able to muscle their way into foreign markets.

It is beyond the scope of this article to evaluate the 'neoclassical' and 'critical political-economic' perspectives in detail. Nevertheless, as Lee $(2008,120)$ points out, 'both can be regarded as offering useful insights and conceptual tools for empirical analysis'. Thus, while the notion of 'cultural discount' provides a useful starting point for understanding why the UK market for European film is so small, it is also important to consider the wider political-economic or industrial context in which European films are produced, distributed and consumed, including 'how state policies combine with business strategies to shape the parameters for and characters of the transnational flow of media products' (Lee 2008, 120).

\section{Language, cultural content and aesthetic style}

The main reason why European films face such a high 'cultural discount' in the UK market is due to the fact that three-quarters are non-English or 'foreign-language' productions - which are generally screened with English subtitles rather than dubbed, as is the case in France or Germany. At the same time, the fact that Britain shares a common language with the US, not to mention a long history of engagement with American popular culture going back to the early twentieth century (see Higson and Matlby 2000), means that US films are more easily accepted by British audiences, which partly explains why even 'specialised' US films generally outperform their European counterparts. ${ }^{3}$

Audience research confirms that foreign-language films have less appeal in the UK than English-language productions. A BFI (2011) survey, for example, found while almost half of Britons had seen a foreign-language title in the last 12 months, only 
$14.1 \%$ liked this type of film - one of the least popular genres selected (figure 2).

Moreover, just 2.3\% said they watched foreign-language films 'most often'. While the BFI survey did not explore why the majority of Britons dislike foreign-language films, it is likely many are put off by subtitles, which can be difficult to follow, do not always convey the full-meaning of the story, and require considerable concentration (Kilborn 1993; Mera 1999; Pelletier 2012). Children and the elderly or those with poor eye-sight or low literacy skills can find it especially hard to watch subtitled films (which is why foreign-language family films and animations are normally dubbed for the UK market).

[figure 2 here]

Language is not the only reason why European films suffer a heavy cultural discount in the UK, however. Their cultural content and aesthetic style can also diminish their appeal. European films often feature actors, characters, settings and subject matter which British audiences are unfamiliar with. Many are also seen as 'arthouse' films. In common usage, this refers to 'feature-length narrative films at the margins of mainstream cinema, located somewhere between fully experimental films and overtly commercial products', and which by the standards of mainstream cinema 'might be seen as too slow or excessive in its visual style, use of color, or characterisation' (Galt and Schoonover 2010, 6. See also Bordwell 1979). However, as recent theoretical debates in this area makes clear (e.g. Andrews 2010), 'art-house' cannot be reduced to a set of intrinsic formal qualities, but instead should be seen as a category that is constructed through various institutional or industrial discourses. We see this, for example, in the way that many European films are regarded as 'mainstream' in their home market, only to be marketed as 'art-house' films when screened abroad. 
The aforementioned BFI survey confirms that films with unfamiliar actors or art-house qualities are less popular with British audiences. The films which Britons said they watched 'most often' were 'blockbusters with big-budget effects and a star cast' (49.9\%), followed by 'films without special effects, but with famous cast members (17.8\%). Only $13.6 \%$ said they liked art-house films, while there were none who watched these types of films 'most often' (figure 2).

It is important to note that those Britons who do enjoy foreign language or art house films tend to conform to a particular demographic profile (table 2). Deeper analysis of the BFI survey data reveals that a higher proportion than average are university graduates, aged $25-55$, earning over $£ 30,000$ per year and urban-dwellers, with significantly more living in London than any other part of the UK. ${ }^{4}$ They tend to be heavier film consumers than the population as a whole and are more culturally engaged: $40.9 \%$ of foreign-language film fans said they visited the cinema at least once a month (compared with $29.0 \%$ of the population), while $37.6 \%$ (compared with $21.2 \%$ of the population) had visited a museum, art gallery, concert or theatre performance. Tellingly, foreign language film fans were significantly more likely than the population as a whole to say they were 'very interested' in 'different languages' $(28.2 \%$ compared with $10.2 \%)$ and 'knowing/finding out about different groups around the world' (42.5\% compared with $23.6 \%$ ). In other words, those Britons most likely to engage with European film - particularly foreign-language titles - are people who possess higher levels of education and cultural capital than the UK population as a whole as well as a more cosmopolitan outlook. ${ }^{5}$

\begin{tabular}{|l|l|r|r|}
\hline & & Foreign-language & Art-house \\
\hline Overall average & & $14.1 \%$ & $13.6 \%$ \\
\hline \multirow{3}{*}{ Education } & No qualification & $5.0 \%$ & $4.3 \%$ \\
\cline { 2 - 4 } & GCSE (or equivalent vocational) & $8.0 \%$ & $7.6 \%$ \\
\cline { 2 - 4 } & A Levels (or equivalent vocational) & $11.5 \%$ & $10.3 \%$ \\
\cline { 2 - 4 } & Degree or above & $22.0 \%^{*}$ & $21.7 \%^{*}$ \\
\hline
\end{tabular}




\begin{tabular}{|c|c|c|c|}
\hline \multirow[t]{4}{*}{ Age } & $15-24$ & $12.6 \%$ & $10.1 \%$ \\
\hline & $25-34$ & $19.5 \% *$ & $14.7 \%$ \\
\hline & $35-54$ & $14.9 \%$ & $16.3 \% *$ \\
\hline & $55+$ & $10.9 \%$ & $11.6 \%$ \\
\hline \multirow[t]{4}{*}{ Place of residency } & A city & $24.5 \% *$ & $23.2 \% *$ \\
\hline & A suburb of a city & $13.6 \%$ & $13.4 \%$ \\
\hline & A town & $12.1 \%$ & $11.5 \%$ \\
\hline & A village or rural area & $8.5 \%$ & $8.6 \%$ \\
\hline \multirow[t]{12}{*}{ Region } & North & $7.5 \%$ & $11.6 \%$ \\
\hline & North West & $13.7 \%$ & $12.9 \%$ \\
\hline & Yorkshire \& Humberside & $13.5 \%$ & $14.0 \%$ \\
\hline & West Midlands & $8.0 \%$ & $10.3 \%$ \\
\hline & East Midlands & $8.7 \%$ & $9.0 \%$ \\
\hline & East Anglia & $9.8 \%$ & $11.6 \%$ \\
\hline & South West & $14.5 \%$ & $12.6 \%$ \\
\hline & South East & $15.1 \%$ & $12.4 \%$ \\
\hline & Greater London & $23.1 \% *$ & $21.5 \% *$ \\
\hline & Wales & $9.2 \%$ & $10.9 \%$ \\
\hline & Scotland & $17.6 \%$ & $16.3 \%$ \\
\hline & N. Ireland & $18.1 \%$ & $16.4 \%$ \\
\hline \multirow[t]{2}{*}{ Gender } & Male & $14.4 \%$ & $14.1 \%$ \\
\hline & Female & $13.9 \%$ & $13.2 \%$ \\
\hline \multirow[t]{2}{*}{ Income } & Under $£ 30,000$ & $13.7 \%$ & $12.2 \%$ \\
\hline & $£ 30,000$ or more & $16.4 \%^{*}$ & $16.7 \% *$ \\
\hline \multirow[t]{2}{*}{ Ethnicity } & White & $13.7 \%$ & $13.7 \%$ \\
\hline & Other & $21.0 \%$ & $11.5 \%$ \\
\hline
\end{tabular}

Table 2. Demographic profile for British film viewers who like 'foreign-language' and 'art-house' films. (*indicates significant differences from the mean at the $\mathrm{p}=0.05$ level). Source: BFI 2011.

\section{Production, distribution and exhibition}

While the notion of 'cultural discount' goes a long way to explaining why the UK market for European film is so small, it is also important (as noted above) to take account of the wider political-economic context within which European films are produced, distributed and exhibited. According to Henning and Alpar (2005), the European film industry faces two principal problems: high fragmentation of the production sector, and weak distributors and low level of vertical integration. These lead to small production sizes and budget restraints, resulting in weak marketing efforts and shortfalls in development. Consequently, Europe produces lots of low budget films that lack both the production values (in terms of stars or special effects) and the marketing and distribution clout to compete with Hollywood productions.

These structural weaknesses affect many of the European films released in the UK. The average French or German film, for example, has a production budget of 
around \$5 million, compared with $£ 139$ million for a major Hollywood production (Mueller 2011). Analysis of data from the EAO's LUMIERE database suggests that almost three-quarters (73.2\%) of European films released in the UK between 2007 and 2012 were handled by small, specialist independent distributors (which control only 5\% of the UK box office), such as Curzon Artificial Eye, New Wave and Soda Pictures. According to the UKFC/BFI's Statistical Yearbooks (2003-2014), foreign-language European films reach about 14 theatres at their widest point of release, compared with about 168 for the average English language production. Meanwhile, only $7 \%$ of UK cinema screens are devoted to 'specialised' films (which includes foreign-language productions), with most concentrated in London or other major cities (BFI 2014, 112).

Efforts have been made to overcome these structural problems. The EU's MEDIA programme, for example, awarded $€ 8.6$ million to UK distributors between 2007 and 2013 to support the distribution of 219 European films (MEDIA Desk UK 2008-14). It also granted an additional $€ 5.2$ million to the Europa Cinema Network, a chain of 50 or more UK cinemas which specialise in European film. In the same period, the UKFC (and subsequently the BFI) awarded UK distributors £5.6 million (€6.8 million) to support the release of 111 European titles through its Prints and Advertising (P\&A) Fund (see UKFC/BFI Annual Reports 2008-14). ${ }^{6}$ In 2005, the UKFC created the Digital Screen Network (DSN), a £11.7 million scheme through which cinemas could get hold of a $£ 50,000$ high definition digital projector in return for agreeing to show more British independent films and 'specialised' titles including foreign-language European films (BFI 2015). By 2009, one-in-four UK cinemas had benefited from the DSN scheme, boosting the number of specialised screenings by 165,000 .

However, these interventions have had only marginal impact. While admissions for European films grew in the UK by $70.0 \%$ during the period 2007 to 2013, from 2.9 
million to 5.0 million, much of this growth can be attributed to English-language productions - which accounted for about $80.0 \%$ of total European film admissions in 2013 (figure 3). Indeed, most ticket sales went on just one or two titles per year. For example, the French-made Hollywood-style action blockbuster Taken (Morel, France/US/UK, 2008) accounted for 33\% of the total admissions for European films in 2008, while its sequel, Taken 2 (Megaton, France, 2012), took a 45\% share in 2012. Neither film received any support from either MEDIA or the BFI. Meanwhile, total admissions for foreign-language European films - half of which did receive MEDIA distribution support - fell by $46.8 \%$ from 1.9 million in 2007 to 1.0 million in 2013 .

[figure 3 near here]

\section{Current challenges within the UK market for European film}

Interviews with industry professionals point to four specific reasons why the market for foreign-language European films has declined in recent years. Firstly, specialised arthouse cinemas, the traditional champions of foreign-language cinema, are showing more mainstream Hollywood films, partly to attract older, middle-class cinemagoers, who tend to shun teen-orientated multiplexes (see Evans 2011). As one distributor put it 'You get cinemas which a few years ago would show a solid arthouse/independent programme [that] are suddenly showing The Hobbit' ${ }^{7}$ This trend is particularly the case within so-called 'art-house chains' (e.g. Picturehouse, Curzon and Everyman), which have expanded significantly in the last few years in order to cater for more 'upmarket' cinemagoers. In 2013, Cineworld, which owns 21 Picturehouse cinemas, was forced to sell three cinemas in Aberdeen, Cambridge and Bury St Edmunds after the Competition Commission ruled that 'although Picturehouse cinemas show art-house and foreign- 
language films, a large proportion of Picturehouse's revenues comes from more mainstream films, in direct competition to Cineworld' (BBC News Website 2013).

Secondly, multiplex cinemas, which account for $40 \%$ of the country's cinemas and $76 \%$ of screens, are showing fewer foreign-language European films compared with a decade ago. In 2001, the French-owned UGC chain, which operated 34 multiplex cinemas in the UK, launched its own British distribution label, UGC Films UK, which specialised in European films (Romney 2001). Building on the unprecedented success of foreign-language titles like Amélie (Jeunet, France/Germany, 2001) and Crouching Tiger Hidden Dragon (Lee, Taiwan/China/Hong Kong/USA, 2000), the new label achieved early breakout successes with Good Bye Lenin! (Becker, Germany 2003), Swimming Pool (Ozon, France/UK 2003) and 8 Femmes (Ozon, France 2002). This was partly helped by UGC's loyalty card scheme, which allowed unlimited entry to UGC cinemas for a relatively low monthly fee, and so encouraged audiences 'to take a risk' and 'see things they hadn't seen before', including foreign-language European films. ${ }^{8}$ Although UGC Films UK closed down following Cineworld's takeover of the UGC chain in 2005 , it set a precedent which was followed by other multiplex cinemas with the support of the UKFC's DSN scheme (see above). However, once the DSN scheme ended with the closure of the UKFC in 2010, most multiplexes reverted to a more mainstream programme.

The third reason why admissions for foreign-language European films have declined in recent years is increased competition. Over the past decade, the number of films released in the UK each year has almost doubled, from 369 in 2002 to 698 in 2013 (BFI 2014), partly as new digital technology has lowered production costs. With so many new releases each week (not to mention alternative cinema content such as live theatre or opera), it has become harder for smaller titles to standout. As one distributor 
explained, 'The big weekly film release tends to get quite a lot written about it while everything else gets a couple of paragraphs'. ${ }^{9}$ The constant churn of new releases also makes it difficult for foreign-language European films to build an audience through positive word-of-mouth. On average, subtitled films remain only four weeks in UK cinemas, down from six weeks in 2012 (BFI 2014, 20). Many only receive one-off screenings during off-peak hours, as with the Picturehouse 'Discover Tuesday' slot.

Finally, the cost of releasing foreign-language European films has increased. In order to contribute to the massive costs of converting all UK cinemas to digital, distributors have been forced to pay a Virtual Print Fee (VPF), calculated to match the amount they would have spent on producing and shipping physical $35 \mathrm{~mm}$ prints. But while the VPF has worked well for mainstream Hollywood studio releases, some independent distributors complain it actually makes smaller, platform releases - which is how most foreign-language European films are introduced to the market - more expensive (Lodderhose 2010; Macnab 2016). As one independent distributor explained, 'The Virtual Print Fee will effectively charge you $£ 500$ if you want to move your digital print of a film from one cinema to the next. It therefore acts a considerable disincentive to the wider circulation of European films'. ${ }^{10}$

\section{Why some European films achieve breakout success}

While most European films struggle in the UK market, some do manage to 'breakout' each year. These are defined by the industry as films which have secured at least $£ 1$ million (about 200,000 admissions) at the UK box office. Using this figure as a benchmark, 34 films (6.7\% of European releases) were identified as breakout titles from a database of 504 European films released in the UK in the period 2007-13 (table 1). ${ }^{11}$ Two-thirds were English language films, while the remainder were foreign-language 
titles. The English-language productions can be further divided into action blockbusters (9 films), animations (7) and dramas (5).

\section{English-language European films}

English-language European films understandably perform well in the UK because they suffer less cultural discount. European action blockbusters are particularly likely to achieve breakout success because they are designed with qualities (e.g. big budget special effects and a star cast) that appeal to mainstream British audiences. Though some of these films do feature foreign European characters and settings, their 'heroes' are generally British or American, while their 'villains' tend to be European 'Others', often from eastern Europe. In Taken, for example, Liam Neeson plays a former CIA operative who sets about tracking down his daughter after she is kidnapped by Albanian human traffickers for sexual slavery while traveling in France.

Other English-language European films find it harder to breakout: only $25.9 \%$ of animations and $8 \%$ of dramas achieved breakout success in the period 2007-13. The most successful European animations tend to feature cast members which British audiences are familiar with. Animals United (Klooss \& Tappe, Germany, 2010), for example, was voiced by the well-known English comedians Stephen Fry and James Corden, while Arthur and the Invisibles (Besson, France, 2007) featured the musicians Madonna and David Bowie. The most successful European animations also tend to imitate popular Disney/Pixar or DreamWorks animations. Indeed, Animals United was described by one online blogger as 'a blatant rip off of the far superior Madagascar' (Smiles 2012), while The Guardian's Peter Bradshaw called Sammy's Adventures (Stassen, Belgium/USA, 2011) 'the poor cousin of Finding Nemo' (Bradshaw 2011). By 
comparison, those European animations which perform less well in the UK market tend to be ones which are more culturally distinctive in terms of their style and content.

The most successful English-language European dramas likewise tend to feature cast members, characters and settings which British audiences are likely to recognise. The Ghost Writer (Polanski, France/Germany/UK, 2010), for example, stars Scottish actor Ewan McGregor as a writer who is hired to complete the memoirs of a former British Prime Minister (played by the former Bond actor Pierce Brosnan) who has been accused of a possible war crime - a topic which drew obvious comparisons with the Blair premiership when it was released in 2010. Similarly, Cloud Atlas (Tykwer, Wachowski \& Wachowski, Germany/USA, 2013) features Hollywood stars Tom Hanks and Halle Berry, as well as the English actor Jim Broadbent, while The Impossible (Bayona, Spain, 2010) again stars Ewan McGregor alongside Naomi Watts as a Western family caught-up in the 2004 Indian Ocean tsunami. Some English-language European dramas, however, succeed for other reasons. The Artist (Hazanavicius, France/Belgium, 2011), for example, attracted interest partly because of its novel concept (as a modern black-and-white silent film), and partly because of its outstanding reviews and the buzz surrounding its Oscar success. Meanwhile, Silent Hill: Revelation $3 D$ (Bassett, France/USA, 2012) features some familiar British faces (e.g. Sean Bean), but perhaps owed its success more to the fact it was based on a popular video game franchise (also a factor in the success of the Resident Evil films).

Not only do the most successful English-language European films suffer little in terms of cultural discount, but they also face fewer structural problems at the level of production and distribution (table 3). They tend to have higher budgets by European standards and are often co-produced with international partners. They are also largely distributed by Hollywood studios (e.g. $20^{\text {th }}$ Century Fox, Universal or Warner Bros.) or 
major independent distributors (e.g. eOne, Momentum or Studiocanal), and generally receive a 'saturation' release. The average English-language European action blockbuster, for example, reached about half the country's cinemas, in most cases premiering within the top three ranking films, despite receiving poor reviews.

\begin{tabular}{|c|c|c|c|c|c|c|c|c|c|}
\hline & & \multicolumn{2}{|c|}{$\begin{array}{c}\text { English-language action } \\
\text { blockbuster }\end{array}$} & \multicolumn{2}{|c|}{$\begin{array}{c}\text { English-language } \\
\text { animation }\end{array}$} & \multicolumn{2}{|c|}{$\begin{array}{c}\text { English-language } \\
\text { dramas }\end{array}$} & \multicolumn{2}{|c|}{$\begin{array}{l}\text { Foreign-language } \\
\text { films }\end{array}$} \\
\hline & & Breakout & $\begin{array}{c}\text { Not } \\
\text { breakout }\end{array}$ & Breakout & $\begin{array}{c}\text { Not } \\
\text { breakout }\end{array}$ & Breakout & $\begin{array}{c}\text { Not } \\
\text { breakout }\end{array}$ & Breakout & $\begin{array}{c}\text { Not } \\
\text { breakout }\end{array}$ \\
\hline Budget & Budget (\$) & $50,452,856$ & $20,000,000$ & $45,594,480$ & $23,401,245$ & $45,400,000^{*}$ & $16,005,865$ & $12,193,051$ & $9,890,957$ \\
\hline \multirow[t]{2}{*}{ Production category } & Co-production & $77.8 \%$ & $50.0 \%$ & $42.9 \%$ & $70.0 \%$ & $80.0 \%$ & $83.3 \%$ & $38.5 \%$ & $46.3 \%$ \\
\hline & $\begin{array}{l}\text { Domestic } \\
\end{array}$ & $22.2 \%$ & $50.0 \%$ & $57.1 \%$ & $30.0 \%$ & $20.0 \%$ & $16.7 \%$ & $61.5 \%$ & $53.7 \%$ \\
\hline \multirow[t]{3}{*}{ Distribution category } & Hollywood major & $77.8 \%$ & $0.0 \%$ & $14.3 \%$ & $0.0 \%$ & $20.0 \%$ & $7.6 \%$ & $7.7 \%^{*}$ & $0.5 \%$ \\
\hline & Major independent & $11.1 \%$ & $50.0 \%$ & $85.7 \% *$ & $35.0 \%$ & $80 \% *$ & $21.2 \%$ & $76.9 \%^{*}$ & $19.6 \%$ \\
\hline & Specialist independent & $11.1 \%$ & $50.0 \%$ & $0.0 \%$ & $65.0 \%$ & $0.0 \%$ & $71.2 \%$ & $15.4 \%$ & $79.8 \% *$ \\
\hline \multirow[t]{3}{*}{ Admissions } & UK & 929,622 & 95,238 & $591,963.3^{*}$ & 38,102 & $965,410.4^{*}$ & 28,144 & $312,502.4^{*}$ & 18,992 \\
\hline & US & $7,625,568$ & 900,744 & $1,118,342$ & 244,417 & $2,491,834.2^{*}$ & 57,995 & $771,972.6^{*}$ & 30,147 \\
\hline & Europe & $5,197,970$ & 763,267 & $4,833,483.6^{*}$ & $1,299,339$ & $6,634,473$ & 512,819 & $7,167,023.6^{*}$ & 838,614 \\
\hline \multirow[t]{2}{*}{ Distribution support } & $\operatorname{MEDIA}(€)$ & - & - & - & 7,856 & - & 19,512 & 12,520 & 15,755 \\
\hline & $\mathrm{BFI}(€)$ & - & - & - & 20,508 & - & 9,924 & $120,972.2^{*}$ & 11,012 \\
\hline \multirow[t]{4}{*}{ Release strategy } & Rank & 3.1 & 7 & 4.6 & $20.3^{*}$ & 4.4 & $21.4^{*}$ & 9.6 & $25.9 *$ \\
\hline & Open wk/end & 372.1 & 169 & $401.6^{*}$ & 68.5 & $272.4^{*}$ & 51.3 & $76.6^{*}$ & 17.2 \\
\hline & WRP & 374 & 169.5 & $422.1^{*}$ & 75.4 & 343.8 & 52.5 & $104.6^{*}$ & 19.5 \\
\hline & Weeks & 7.1 & 2.5 & 14.4 & 13.6 & 9.4 & 6.3 & $16.7^{*}$ & 6.5 \\
\hline \multirow[t]{2}{*}{ Audience rating } & $\mathrm{IMDb}$ & 6.2 & 6.4 & 6.2 & 6.3 & 7.1 & 6.7 & $7.7^{*}$ & 6.8 \\
\hline & Rotten Tomatoes & 54.8 & 74 & 42.3 & $63.1^{*}$ & 68.8 & 61.2 & $76.7^{*}$ & 65.2 \\
\hline \multirow[t]{2}{*}{ Critics rating } & $\mathrm{IMDb}$ & 40 & $54.5^{*}$ & 39 & 64.3 & 61.8 & 58.6 & 73.4 & 69.5 \\
\hline & Rotten Tomatoes & 36.6 & 75 & 32 & 58 & 66.6 & 62.1 & 80.3 & 78.2 \\
\hline \multirow[t]{2}{*}{ Awards } & Awards & 1 & 3.5 & 0.7 & 2.9 & $37.4^{*}$ & 5.2 & $22.1^{*}$ & 5.9 \\
\hline & Nominations & 2.7 & 7 & 2.3 & 6.3 & $48.8^{*}$ & 6.1 & $23.3^{*}$ & 7.8 \\
\hline
\end{tabular}

Table 3. Production, distribution and box office profile of European films by language/genre. (*indicates significant differences from the mean at the $\mathrm{p}=0.05$ level). Sources: LUMIERE / MEDIA / BFI / Rotten Tomatoes / Box Office Mojo.

\section{Foreign-language European films}

It is perhaps unsurprising that English-language European films perform well in the UK.

What is potentially more interesting to debates about the transnational media flow is why some foreign-language European titles also manage to achieve breakout success.

Of the 395 foreign-language European films released in Britain in the period 2007-13, there were only 13 (3.3\% of European releases) which sold more than 200,000 cinema tickets. Analysis of BFI cinema exit polls, which are available for seven of the 13 films, provide some indication why these particular titles proved popular with British audiences (table 4). ${ }^{12}$ When asked what attracted them to see the film in question (the 'bait to attendance'), one of the most common responses was simply, 'The story 
appealed to me'. This may seem a rather vague explanation, but it does indicate that the most successful foreign-language European films are ones with clear plots, a quality which, according to a European Commission $(2014,162)$ survey, more than half of British audiences (53\%) feel is often lacking in European films. This is not to suggest their stories and characters are simplistic - they may be quite complex as in the case of the French thriller Tell No One (Canet, France, 2007) - but they perhaps place more emphasis on narrative than the qualities most associated with art-house films, such as excessive visual style.

\begin{tabular}{|c|c|c|c|c|c|c|c|c|}
\hline Baits to attendance & $\begin{array}{c}\text { The Lives of } \\
\text { Others }\end{array}$ & $\begin{array}{l}\text { Coco } \\
\text { Before } \\
\text { Chanel }\end{array}$ & $\begin{array}{l}\text { Let the } \\
\text { Right One } \\
\text { In }\end{array}$ & Tell No One & $\begin{array}{l}\text { The Girl } \\
\text { with the } \\
\text { Dragon } \\
\text { Tattoo }\end{array}$ & $\begin{array}{l}\text { Broken } \\
\text { Embraces }\end{array}$ & $\begin{array}{l}\text { The Skin I } \\
\text { Live In }\end{array}$ & Average \\
\hline The story appealed to me & $52 \%$ & $50 \%$ & $46 \%$ & $41 \% *$ & $28 \%$ & $17 \%$ & $27 \%$ & $37 \% *$ \\
\hline Genre / type of film & $42 \%$ & $26 \%$ & $36 \%$ & $35 \%$ & $18 \%$ & $28 \%$ & $31 \%$ & $31 \%$ \\
\hline Reviews & $56 \% *$ & $12 \%$ & $56 \% *$ & $31 \%$ & $24 \%$ & $0 \%$ & $28 \%$ & $30 \%$ \\
\hline Director & $0 \%$ & $2 \%$ & $0 \%$ & $6 \%$ & $0 \%$ & $74 \% *$ & $74 \% *$ & $22 \%$ \\
\hline Star & $0 \%$ & $32 \%$ & $0 \%$ & $7 \%$ & $0 \%$ & $49 \%$ & $36 \%$ & $18 \%$ \\
\hline Asked by friend / partner & $0 \%$ & $10 \%$ & $32 \%$ & $11 \%$ & $17 \%$ & $21 \%$ & $20 \%$ & $16 \%$ \\
\hline Advertising / poster & $14 \%$ & $14 \%$ & $13 \%$ & $18 \%$ & $10 \%$ & $11 \%$ & $10 \%$ & $13 \%$ \\
\hline Subject matter & $0 \%$ & $53 \% *$ & $0 \%$ & $0 \%$ & $0 \%$ & $0 \%$ & $14 \%$ & $8 \%$ \\
\hline Source material (e.g. book) & $0 \%$ & $0 \%$ & $0 \%$ & $7 \%$ & $43 \% *$ & $0 \%$ & $0 \%$ & $8 \%$ \\
\hline Trailer & $21 \%$ & $0 \%$ & $0 \%$ & $0 \%$ & $9 \%$ & $14 \%$ & $0 \%$ & $7 \%$ \\
\hline Award & $28 \%$ & $0 \%$ & $0 \%$ & $0 \%$ & $0 \%$ & $0 \%$ & $8 \%$ & $5 \%$ \\
\hline Friends talking about it & $0 \%$ & $9 \%$ & $0 \%$ & $5 \%$ & $16 \%$ & $0 \%$ & $29 \%$ & $5 \%$ \\
\hline Nationality of film & $0 \%$ & $0 \%$ & $0 \%$ & $5 \%$ & $0 \%$ & $0 \%$ & $0 \%$ & $4 \%$ \\
\hline Cast members & $0 \%$ & $3 \%$ & $0 \%$ & $6 \%$ & $0 \%$ & $0 \%$ & $12 \%$ & $3 \%$ \\
\hline Shown at festival & $0 \%$ & $0 \%$ & $0 \%$ & $0 \%$ & $0 \%$ & $0 \%$ & $0 \%$ & $0 \%$ \\
\hline
\end{tabular}

Table 4. Key 'baits to attendance' for 'breakout' foreign-language European films. (*indicates highest ranked bait). Sources: UKFC/BFI 2007-13.

The other key 'baits for attendance' were 'genre/type of film' and 'reviews'. The latter was particularly important to the appeal of the German Cold War drama The Lives of Others and the Swedish horror Let The Right One In (Alfredson, Sweden, 2009). The importance which distributors place on reviews can be seen in the way five-star ratings and choice quotes are often used in trailers and posters to promote foreign-language European films. One distributor even claimed that The Guardian's chief film critic Peter Bradshaw 'can make or break a film' within this market. ${ }^{13}$ Critically-acclaimed 
European films do not always achieve breakout success. For example, the Romanian film 4 Months, 3 Weeks and 2 Days (Mungiu, Romania, 2007), one of the highest rated European films according to IMDb's 'Metacritic' aggregator, sold only 58,005 tickets in the UK. Nevertheless, regardless whether they are five-stars or not, reviews build public awareness and provide important sources of information about the film's story, which as we have seen, is one of the key draws for audiences.

Although 'story', 'genre' and 'reviews' were the top three 'baits to attendance' on average, they were not key in every case. For The Skin I Live In (Almodóvar, Spain, 2011) and Broken Embraces, the 'director' was the highest rated bait to attendance; for Coco Before Chanel, it was 'subject matter'; and for The Girl with the Dragon Tattoo, it was 'source material'. Analysis of all 173 exit polls conducted by the UKFC/BFI between 2005 and 2015 suggest that cinemagoers are rarely drawn to foreign-language European films because of the film's director, subject matter or source material. However, in the case of the most successful foreign-language European films, we have examples where these elements are quite well-known to British audiences. For example, Pedro Almodóvar, the director of Broken Embraces and The Skin I Live In, is, as one veteran UK distributor put it, 'one of the few big-named directors left [in Europe]'. ${ }^{14}$ Similarly, the subject of Coco Before Channel is a global fashion icon, while the source material for The Girl with the Dragon Tattoo is an internationally best-selling book.

In general, then, foreign-language European films are likely to breakout if they possess what distributors call 'pre-sold' elements - things which audiences are already familiar with. In cases where films do not possess any pre-sold elements, they must instead rely on the appeal of their story, genre and reviews. Either way, the key factor seems to be the degree to which audiences can identify with some aspect of the film. Of course, for the 'core' foreign-language film audience the 'otherness' and 'exoticism' of 
these films may be a key part of their appeal - as we have seen, foreign-language film fans often enjoy learning about other cultures. Yet for such films to crossover to a more mainstream audience (and so become a breakout title), they also need to include some element of cultural familiarity. Without that element of cultural familiarity, mainstream audiences are unlikely to invest the time and money to watch a foreign-language European film in the cinema (though they might do so on a free-to-view platform).

Yet important as a film's cultural content may be to its audience appeal, breakout foreign-language European films still owe a large part of their success to industrial factors (table 3). While their production budgets are not particularly high, these films are typically backed by powerful distributors. Compare, for example, Coco Before Chanel, which was distributed by Studiocanal, a major independent distributor, with the box office flop Coco Chanel and Igor Stravinsky (Kounen, France, 2009), which was released by Soda Pictures, a specialist independent distributor. $84.6 \%$ of breakout foreign-language European films were distributed by either Hollywood studios or major independent distributors, compared with only $20.1 \%$ in the case of their nonbreakout counterparts (table 3). As such, they opened in four times as many theatres (76.6 theatres compared with 17.2), reached five times as many theatres at their widest point of release (104.6 theatres compared with 19.5), and lasted two and a half times as long in cinemas (16.7 weeks compared with 6.5).

In terms of distribution support, breakout foreign-language European films actually received less MEDIA funding than their non-breakout counterparts (an average of $€ 12,520$ per film compared with $€ 15,755)$, but significantly more support from the BFI's P\&A scheme (€120,972 per film compared with $€ 11,011)$, with nine of the 11 breakout films receiving BFI funding. This is revealing because BFI distribution support tends to be more effective than MEDIA funding. For example, a film with a BFI 
award of $€ 40,000$ can be predicted (using linear regression analysis) to secure 12,000 more admissions than one with the same amount of funding from the MEDIA programme. This difference can be explained by the fact that the average BFI award tends to be almost twice as large as the average MEDIA award (€61,660 compared with $€ 39,108)$. They are also more selective, specifically targeting foreign-language films which the funding body feels are likely to appeal outside the core audience for specialised films. Unlike the MEDIA programme, the BFI also allows funds to go to UK distributors that are owned by non-European parent companies (e.g. eOne, Icon, Lionsgate) and which tend to have more clout than their European counterparts.

\section{Conclusion}

European films generally perform badly in the UK for two main reasons. Firstly, they face a heavy 'cultural discount' because their language, content and aesthetic style only appeals to a minority of British film viewers. Secondly, they suffer from structural weaknesses at the level of production and distribution. The majority have small budgets and are released by specialist independent distributors which lack market leverage. As such, they do not circulate widely or stay in cinemas long enough to build an audience.

Those European films which do achieve breakout success fall into two camps. Firstly, there are English-language European films which feature qualities which appeal to a mainstream British audience, such as big-budget special effects and famous cast members. Secondly, there are foreign-language European films whose linguistic cultural discount is mitigated by the fact they possess certain 'pre-sold' elements - for example, a well-known story, genre, director, subject matter or source material - which British cinemagoers are already familiar with. In either case, breakout European films are typically backed by either a Hollywood studio or a major independent distributor. 
This suggests that distribution is key to determining whether or not a foreignlanguage European film will achieve breakout success. At the same time, Hollywood studios or major independent distributors will only acquire films which they think have the qualities (e.g. pre-sold elements) which they think will appeal to a large audience and so make more money. In such instances, they will use their financial muscle to secure these films against the competition of smaller, specialist distributors. Success is therefore dependent on a combination of both cultural and industrial factors.

These findings add to the literature on transnational media flow. On the one hand, they confirm that 'cultural discount' is one of the key reasons why films produced in one country do not easily travel to another. On the other hand, they underline the importance of industrial factors such as production, distribution and exhibition in terms of enabling films to travel across borders. That is not to say that a European film distributed by a Hollywood studio is likely to perform well in the UK market - it still needs some cultural elements which British audiences can identify with. But where European films do possess these pre-sold elements they are unlikely to succeed without high investment in distribution and access to cinema space. In other words, cultural discount alone does not explain why some films travel better than others.

In terms of current policy debates, the findings suggest that bodies like the EU's MEDIA programme are right to prioritise investment at the level of distribution and exhibition in order to increase the circulation and viewership of European film. However, as this paper has also shown, these measures could be made more effective. For example, the MEDIA programme could learn from the BFI's P\&A Fund by targeting awards to those European films with familiar cultural elements which British audiences are likely to identify with. It could also make UK distributors owned by non- 
European parent companies (e.g. eOne, Icon, Lionsgate) eligible for distribution support, as these tend to be more powerful than their European-owned counterparts.

Of course, it is also important to point out that cultural familiarity is not innate, but something learnt through education and other forms of socialisation (see Bourdieu 1984) - one reason why those with high cultural capital are most likely to engage with European films (see also Hill 2004). Thus, as well addressing structural weaknesses at the level of distribution, policymakers also need to consider the role which film education and media literacy can play in developing an audience for European film. The decision of the EU's new Creative Europe scheme, which subsumed the MEDIA programme in 2014, to introduce a new strand of funding for 'audience development' suggests European policymakers are beginning to move in this direction.

Yet such reforms to the MEDIA programme may prove to be irrelevant for British cinemagoers. Britain's decision to leave the EU means that in future UK-based distributors may not be eligible for MEDIA distribution support. Some predict that certain European films could disappear from British cinemas as a result. As The Guardian's film editor Andrew Pulver (2016) puts it:

We would probably still get high-profile award-winners such as Dheepan and Son of Saul, but what chance would there be of seeing lesser-known stuff such as Suburra or Long Way North in British cinemas again? They only get here with EU help.

Britain could perhaps opt to remain part of the MEDIA programme like other non-EU countries such as Norway and Iceland. Alternatively, the UK government could use some of the money saved from EU membership to boost the BFI's P\&A fund for 
specialist films. Either way, without a proper understanding of both the cultural factors

(e.g. language, aesthetic style, cultural familiarity) and industrial factors (e.g.

distribution and access to screen space) that influence the box office performance of

European films in the UK, any policy intervention is unlikely to succeed.

\section{Acknowledgements}

This work comes out of the 'Mediating Cultural Encounters through European Screens' (MeCETES) project (www.mecetes.co.uk). MeCETES has received funding from the Humanities in the European Research Area (HERA) Joint Research Programme (www.heranet.info) [grant number 291827]. HERA is co-funded by AHRC, AKA, BMBF via PT-DLR, DASTI, ETAG, FCT, FNR, FNRS, FWF, FWO, HAZU, IRC, LMT, MHEST, NWO, NCN, RANNÍS, RCN, VR and The European Community FP7 2007-2013, under the Socio-economic Sciences and Humanities programme. I would like to thank Professor Andrew Higson for his helpful comments on this article and Ilse Schooneknaep for her assistance with the industry interviews.

\footnotetext{
1 'European films' are defined as feature-length films which have been majority produced in the EU28 member states or European Free Trade Area (i.e. Norway, Iceland, Switzerland and Liechtenstein). The term 'European film' excludes UK films and UK majority co-productions. This is to not to suggest Britain is not a European country, but rather to avoid the more cumbersome (though more accurate) phrase 'non-national European film'.

${ }^{2}$ Interviews were conducted with: Agnieszka Moody (Creative Europe Desk UK); Alex Agran (Arrow Films); Catherine De Forges (Independent Cinema Office); Dan Borgonon (Channel 4); Ed Fletcher (Soda Pictures); Jason Wood (Curzon Cinema/HOME Manchester); Joan Parsons (Sheffield Showroom); Katie Ellen (BFI); Marion Comengre (Studiocanal); Mark Batey (Film Distributors Association); Robert Beeson (New Wave); Sonali Joshi (Day for Night); and Tom Abell (Peccadillo Pictures). Anonymous interviews were also conducted with representatives from the UKFC and the European Commission. ${ }^{3}$ The BFI defines 'specialised' films as 'films that do not sit easily within a mainstream and highly commercial genre'. They include foreign language films, documentaries, classic or archive films, and films which tell a story in an unconventional, challenging way. http://www.bfi.org.uk/filmindustry/lottery-funding-distribution/specialised-films

${ }^{4}$ This analysis was conducted using the BFI survey's SPSS data, which are available online: http://www.bfi.org.uk/about-bfi/policy-strategy/opening-our-eyes-how-film-contributes-culture-uk ${ }^{5}$ It is interesting to note that European film fans share a similar demographic profile to those who, according to pollsters (e.g. Ashcroft 2016), voted for Britain to remain in the EU during the recent referendum.

${ }^{6}$ The BFI's P\&A Fund revamped in January 2013 as the Distribution Fund.
} 
${ }^{7}$ Robert Beeson (New Wave) interview with author, January 22, 2015.

${ }^{8}$ Catherine de Forges (Independent Cinema Office) interview with author, January 30, 2015.

${ }^{9}$ Robert Beeson (New Wave) interview with author, January 22, 2015.

${ }^{10}$ Laurence Gornell (The Works) panel discussion with author at the "UK Film Distribution: What's Changing?" Conference, Regent Street Cinema, London, July 21, 2016. Available online:

https://www.youtube.com/watch?v=XqIUO0OEVmI

${ }^{11}$ The database was created using admissions figures and other data (e.g. country-of-origin, distributor, genre, language, widest point of release, audience and critic ratings) from the LUMIERE database (http://lumiere.obs.coe.int/web/search/), IMDb (http://www.imdb.com/) and Box Office Mojo (http://www.boxofficemojo.com/).

${ }^{12}$ The BFI exit polls are available online: http://www.bfi.org.uk/film-industry/lottery-fundingdistribution/insight-reports-case-studies-audience-research/exit-polls

${ }^{13}$ Tom Abell (Peccadillo Pictures) interview with author, January 21, 2015.

${ }^{14}$ Robert Beeson (New Wave) interview with author, January 22, 2015. 


\section{References}

Andrew, D. 2010. “Towards an Inclusive, Exclusive Approach to Art Cinema”. In Global Art Cinema, edited by R. Galt and K. Schoonover, 62-74. Oxford: Oxford University Press.

Ashcroft, M. 2016. "How the United Kingdom Voted on Thursday... And Why." Lord Ashcroft Polls, June 24. Accessed November 11, 2016. http://lordashcroftpolls.com/2016/06/how-the-united-kingdom-voted-and-why/

BBC News Website. 2013. "Cineworld's Takeover of Picturehouse Chain Faces Probe." BBC News Website, April 30. Accessed January 9, 2016. http://www.bbc.com/news/business-22356317

BFI. 2011. Opening Our Eyes: How Film Contributes to the Culture of the UK. London: BFI.

BFI.2011-2014. Statistical Yearbooks 2011-2014. London: BFI.

BFI. 2015. “Digital Screen Network.” Accessed January 9, 2016. http://www.bfi.org.uk/film-industry/lottery-funding-distribution/closed-awardschemes/digital-screen-network

Bordwell D. (1979). 2002. “The Art Cinema as a Mode of Film Practice.” Reprint. In The European Cinema Reader, edited by C. Fowler, 94-102. London: Routledge.

Bourdieu P. 1984. Distinction: A Social Critique of the Judgement of Taste. Translated by R. Nice. London: Routledge.

Bradshaw P. 2011. "Review: A Turtle's Tale: Sammy's Adventures” The Guardian, March 24. Accessed January 9, 2016. http://www.theguardian.com/film/2011/mar/24/a-turtles-tale-sammys-adventuresreview 
European Commission. 2014. A Profile of Current and Future Audiovisual Audience. Brussels: European Commission.

Evans E. J. 2011. “Superman vs Shrödinger's Cat: Taste, Etiquette and Independent Cinema Audiences as Indirect Communities.” Participations: Journal of Audience and Reception Studies 8 (2): 327-349.

Galt, R. and Schoonover, K. 2010. "Introduction: The Impurity of Art Cinema". In Global Art Cinema, edited by R. Galt and K. Schoonover, 3-27. Oxford: Oxford University Press.

Henning V. and A. Alpar. 2005. "Public Aid Mechanisms in Feature Film Production: the EU MEDIA Plus Programme.” Media, Culture and Society 27 (2): 229-250.

Higson A. and R. Matlby. 1999. "“Film Europe' and 'Film America': An Introduction." In 'Film Europe' and 'Film America': Cinema, Commerce and Cultural Exchange 1920-1939, edited by A. Higson and R. Matlby R, 1-31. Exeter: Exeter University Press.

Hill J. 2004. "UK Film Policy, Cultural Capital and Social Exclusion.” Cultural Trends 13 (2): 29-39.

Hoskins C. and R. Mirus. 1988. "US Dominance of the International Trade in Television Programmes.” Media, Culture and Society 10: 499-515.

Kilborn R. 1993 “Speak My Language: Current Attitudes to Television Subtitling and Dubbing." Media, Culture and Society 15: 641-660.

Lee F. L. F. 2006. "Cultural Discount and Cross-culture Predictability: Examining the Box Office Performance of American Movies in Hong Kong." Journal of Media Economics 19 (4): 259-278. 
Lee F. L. F. 2008. "Hollywood Movies in East Asia: Examining Cultural Discount and Performance Predictability at the Box Office.” Asian Journal of Communication 18 (2): $117-136$.

Lee S. and D. Waterman. 2007. "Theatrical Feature Film Trade in the United States, Europe and Japan since the 1950s: An Empirical Study of the Home Market Effect." Journal of Media Economics 20 (3): 167-188.

Lodderhose, D. "Virtual Print Fees: Unfair to Indies?" Variety, October 2. Accessed November 15, 2016. http://variety.com/2010/digital/news/virtual-print-feesunfair-to-indies-1118024986/

Macnab, G. 2016. "Virtual Print Fee: Cold Comforts.” Screen Daily, March 24. Accessed November 15, 2016. http://www.screendaily.com/features/virtual-printfee-cold-comforts/5101858.article

MEDIA Desk UK. 2008-2014. MEDIA in the UK 2008-2014. London: MEDIA Desk UK.

MEDIA Salles. 2012. "European Cinema Yearbook 2012.” Accessed January 9, 2016. http://www.mediasalles.it/ybk2012/index.html

Mera M. 1999. "Read My Lips: Re-evaluating Subtitling and Dubbing in Europe." Links \& Letters 6: 73-85.

Mireille P. 2012. "Subtitling and Dubbing: An Overview of a Few EU Countries." The Annual of Language and Politics and Politics of Identity 6 (2): 129-39.

Mueller A. 2011. "Why Movies Cost So Much to Make.” Investopedia, June 13. Accessed January 9, 2016. http://www.investopedia.com/financialedge/0611/why-movies-cost-so-much-to-make.aspx

Pulver, A. 2016. “Less Cash, Fewer Movies, Meltdown: How Brexit May Affect British Film.” The Guardian, June 24. Accessed November 16, 2016. 
https://www.theguardian.com/film/2016/jun/24/less-cash-fewer-moviesmeltdown-how-brexit-may-affect-the-british-film

Romney J. 2001. “France's UGC to Enter UK Distribution Market.” Screen Daily, December 17. Accessed January 9, 2016. http://www.screendaily.com/francesugc-to-enter-uk-distribution-market/407811.article

Smiles F. 2012. "Review: Animals United.” Letterboxd. Accessed January 9, 2016. http://letterboxd.com/smiles/film/animals-united/

Straubhaar J. D. 2003. “Choosing National TV: Cultural Capital, Language, and Cultural Proximity in Brazil.” In The Impact of International Television: A Paradigm Shift, edited by M. G. Elasmar, 77-110. Mahwah, NJ: Lawrence Erlbaum Associates.

UKFC. 2003-2010. Statistical Yearbook 2003-2010. London: UK Film Council.

UKFC. 2007. “Supporting Specialised Film.” Paper presented by the UK Film Council/Optimistic Media, September 2007. 


\section{Figures captions}

Figure 1. Box office share (\%) for films released in the UK by country of origin, 200213. Source: BFI 2014.

Figure 2. Type of film / genre preferred by British film viewers. Source: BFI 2011.

Figure 3. UK admissions for English-language and foreign-language European films, 2007-13. Source: BFI 2014. 
Figures and tables

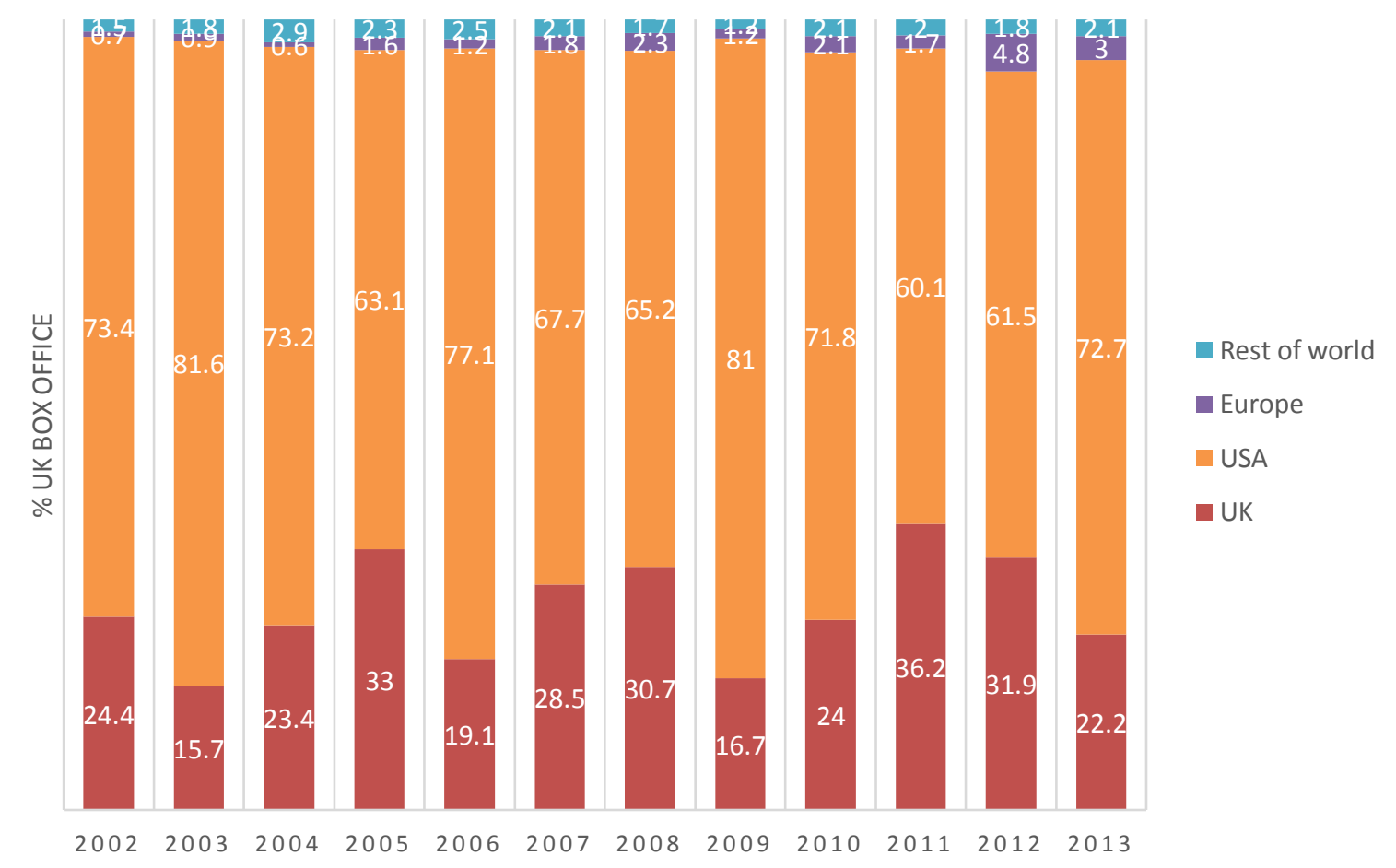

Figure 4. Box office share (\%) for films released in the UK by country of origin, 2002-13. Source: BFI 2014. 


\begin{tabular}{|c|c|c|c|c|c|c|c|}
\hline Film & Year & Lang. & Country & Genre (IMDb) & Directors & UK distributor & UK admissions \\
\hline Taken 2 & 2012 & EN & FR & Action / Crime / Thriller & Olivier Megaton & 20TH CENT. FOX & $3,692,417$ \\
\hline The Impossible & 2013 & EN & ES & Drama / Thriller & Juan Antonio Bayona & eONE & $2,037,493$ \\
\hline The Artist & 2011 & EN & $\mathrm{FR} / \mathrm{BE}$ & Comedy / Drama / Romance & Michel Hazanavicius & ENTERTAINMENT & $1,542,798$ \\
\hline Taken & 2008 & EN & FR / US / GB & Action / Crime / Thriller & Pierre Morel & 20TH CENT. FOX & $1,232,830$ \\
\hline Arthur and the Invisibles & 2007 & FR & FR & Animation / Adventure / Family & Luc Besson & MOMENTUM & $1,090,792$ \\
\hline Planet 51 & 2009 & EN & ES / GB & Animation / Comedy / Animation & Javier Abad / Jorge Blanco & ENTERTAINMENT & 916,506 \\
\hline Resident Evil: Afterlife & 2010 & EN & $\mathrm{DE} / \mathrm{FR} / \mathrm{GB}$ & Action / Adventure / Horror & Paul W.S. Anderson & SONY PICTURES & 815,955 \\
\hline Hitman & 2007 & EN & FR / US & Action / Crime / Drama & Xavier Gens & 20TH CENT. FOX & 726,674 \\
\hline The Ghost Writer & 2010 & EN & FR / DE / GB & Mystery / Thriller & Roman Polanski & STUDIOCANAL & 699,720 \\
\hline The Three Musketeers & 2011 & EN & $\mathrm{DE} / \mathrm{GB} / \mathrm{FR}$ & Action / Adventure / Romance & Paul W.S. Anderson & eONE & 573,764 \\
\hline A Monster in Paris & 2012 & FR & FR & Animation / Adventure / Comedy & Bibo Bergeron & eONE & 534,717 \\
\hline The Lives of Others & 2007 & DE & DE & Drama / Thriller & Florian Henckel von Donnersmarck & LIONSGATE & 534,610 \\
\hline Transporter 3 & 2008 & EN & FR / GB & Action / Adventure / Crime & Olivier Megaton & ICON & 496,334 \\
\hline Justin and the Knights of Valour & 2013 & EN & ES & Animation / Adventure / Family & Manuel Sicilia & eONE & 495,054 \\
\hline Coco Before Chanel & 2009 & FR & FR & Biography / Drama & Anne Fontaine & OPTIMUM & 482,884 \\
\hline Animals United & 2010 & DE & DE & Animation / Comedy / Animation & Reinhard Klooss / Holger Tappe & ENTERTAINMENT & 447,765 \\
\hline Sammy's Adventures: A Turtles Tale & 2011 & NL & BE / US & Animation / Adventure / Family & Ben Stassen & STUDIOCANAL & 388,076 \\
\hline The Girl with the Dragon Tattoo & 2010 & SV & SE / DK / DE & Mystery / Thriller & Niels Arden Oplev & SONY PICTURES & 367,459 \\
\hline The Orphanage & 2008 & ES & ES & Drama / Mystery / Thriller & Juan Antonio Bayona & OPTIMUM & 341,453 \\
\hline La Vie En Rose & 2007 & $F R$ & FR / CZ / GB & Biography / Drama / Music & Olivier Dahan & ICON & 335,568 \\
\hline The Intouchables & 2012 & $F R$ & FR & Biography / Comedy / Drama & Olivier Nakache / Eric Toledano & ENTERTAINMENT & 319,556 \\
\hline From Paris with Love & 2010 & EN & FR & Action / Crime / Thriller & Pierre Morel & WARNER BROS. & 309,557 \\
\hline Resident Evil: Retribution & 2012 & EN & DE / CA / US & Action / Horror & Paul W.S. Anderson & SONY PICTURES & 292,751 \\
\hline Silent Hill: Revelation 3D & 2012 & EN & FR / US & Horror / Mystery / Thriller & Michael J. Bassett & LIONSGATE & 290,295 \\
\hline The Girl who Played with Fire & 2010 & SV & SE / DK / DE & Crime / Drama / Mystery & Daniel Alfredson & MOMENTUM & 279,038 \\
\hline Sammy's Adventures 2 & 2013 & EN & $\mathrm{BE} / \mathrm{FR} / \mathrm{IT}$ & Animation / Adventure / Family & Vincent Kesteloot, Ben Stassen & WARNER BROS. & 270,833 \\
\hline Cloud Atlas & 2013 & EN & DE / US & Drama / Sci-fi & Tom Tykwer, Andy Wachowski & WARNER BROS. & 256,746 \\
\hline Broken Embraces & 2009 & ES & ES & Drama / Romance / Thriller & Pedro Almodóvar & PATHE & 250,642 \\
\hline The Skin I Live In & 2011 & ES & ES & Drama / Horror / Thriller & Pedro Almodóvar & PATHE & 248,487 \\
\hline I've Love You So Long & 2008 & FR & FR / DE & Drama & Philippe Claudel & (LIONSGATE) & 236,025 \\
\hline Tell No One & 2007 & FR & FR & Crime / Drama / Mystery & Guillaume Canet & REVOLVER & 235,720 \\
\hline Babylon A.D. & 2008 & EN & FR / US & Action / Adventure / Sci-Fi & Mathieu Kassovitz & 20TH CENT. FOX & 226,316 \\
\hline Head Hunters & 2012 & NO & $\mathrm{NO} / \mathrm{DE}$ & Crime / Thriller & Morten Tyldum & MOMENTUM & 225,837 \\
\hline Let The Right One In & 2009 & SV & SE & Drama / Horror & Tomas Alfredson & MOMENTUM & 205,252 \\
\hline
\end{tabular}

Table 5. 'Breakout' European films with over 200,000 cinemas admissions ( $\notin$ I million box office) or more in the UK, 2007- | 3. Sources: BFI / LUMIERE / IMDb. 


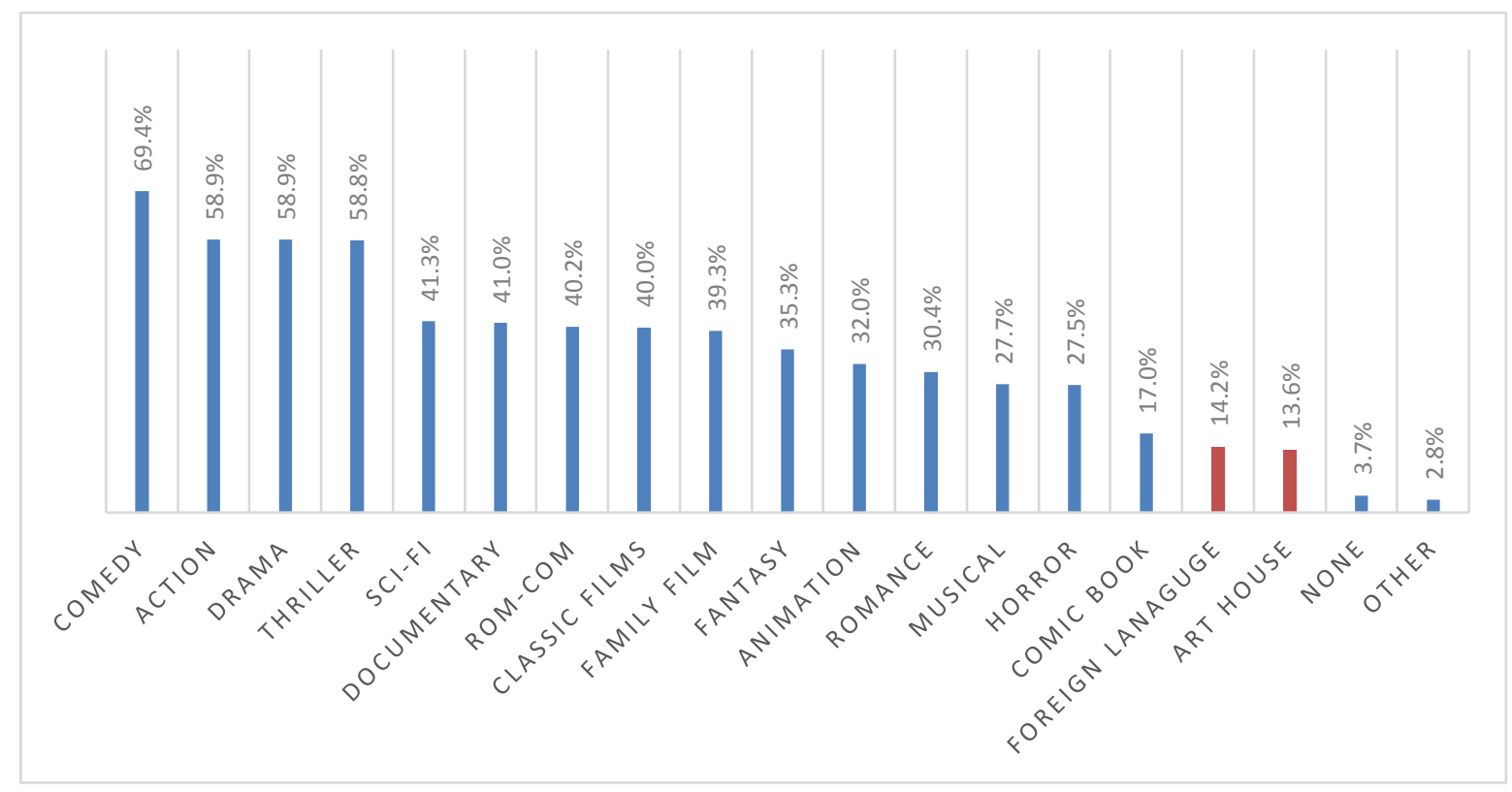

Figure 5. Type of film / genre preferred by British film viewers. Source: BFI 20 I I. 


\begin{tabular}{|c|c|c|c|}
\hline & & Foreign-language & Art-house \\
\hline Overall average & & $14.1 \%$ & $13.6 \%$ \\
\hline \multirow[t]{4}{*}{ Education } & No qualification & $5.0 \%$ & $4.3 \%$ \\
\hline & GCSE (or equivalent vocational) & $8.0 \%$ & $7.6 \%$ \\
\hline & A Levels (or equivalent vocational) & $11.5 \%$ & $10.3 \%$ \\
\hline & Degree or above & $22.0 \% *$ & $21.7 \% *$ \\
\hline \multirow[t]{4}{*}{ Age } & $15-24$ & $12.6 \%$ & $10.1 \%$ \\
\hline & $25-34$ & $19.5 \% *$ & $14.7 \%$ \\
\hline & $35-54$ & $14.9 \%$ & $16.3 \% *$ \\
\hline & $55+$ & $10.9 \%$ & $11.6 \%$ \\
\hline \multirow[t]{4}{*}{ Place of residency } & A city & $24.5 \% *$ & $23.2 \% *$ \\
\hline & A suburb of a city & $13.6 \%$ & $13.4 \%$ \\
\hline & A town & $12.1 \%$ & $11.5 \%$ \\
\hline & A village or rural area & $8.5 \%$ & $8.6 \%$ \\
\hline \multirow[t]{12}{*}{ Region } & North & $7.5 \%$ & $11.6 \%$ \\
\hline & North West & $13.7 \%$ & $12.9 \%$ \\
\hline & Yorkshire \& Humberside & $13.5 \%$ & $14.0 \%$ \\
\hline & West Midlands & $8.0 \%$ & $10.3 \%$ \\
\hline & East Midlands & $8.7 \%$ & $9.0 \%$ \\
\hline & East Anglia & $9.8 \%$ & $11.6 \%$ \\
\hline & South West & $14.5 \%$ & $12.6 \%$ \\
\hline & South East & $15.1 \%$ & $12.4 \%$ \\
\hline & Greater London & $23.1 \% *$ & $21.5 \% *$ \\
\hline & Wales & $9.2 \%$ & $10.9 \%$ \\
\hline & Scotland & $17.6 \%$ & $16.3 \%$ \\
\hline & N. Ireland & $18.1 \%$ & $16.4 \%$ \\
\hline \multirow[t]{2}{*}{ Gender } & Male & $14.4 \%$ & $14.1 \%$ \\
\hline & Female & $13.9 \%$ & $13.2 \%$ \\
\hline \multirow[t]{2}{*}{ Income } & Under $£ 30,000$ & $13.7 \%$ & $12.2 \%$ \\
\hline & $£ 30,000$ or more & $16.4 \% *$ & $16.7 \% *$ \\
\hline \multirow[t]{2}{*}{ Ethnicity } & White & $13.7 \%$ & $13.7 \%$ \\
\hline & Other & $21.0 \%$ & $11.5 \%$ \\
\hline
\end{tabular}

Table 6. Demographic profile for British film viewers who like 'foreign-language' and 'art-house' films. (*indicates significant differences from the mean at the $p=0.05$ level). Source: BFI 20 I I. 


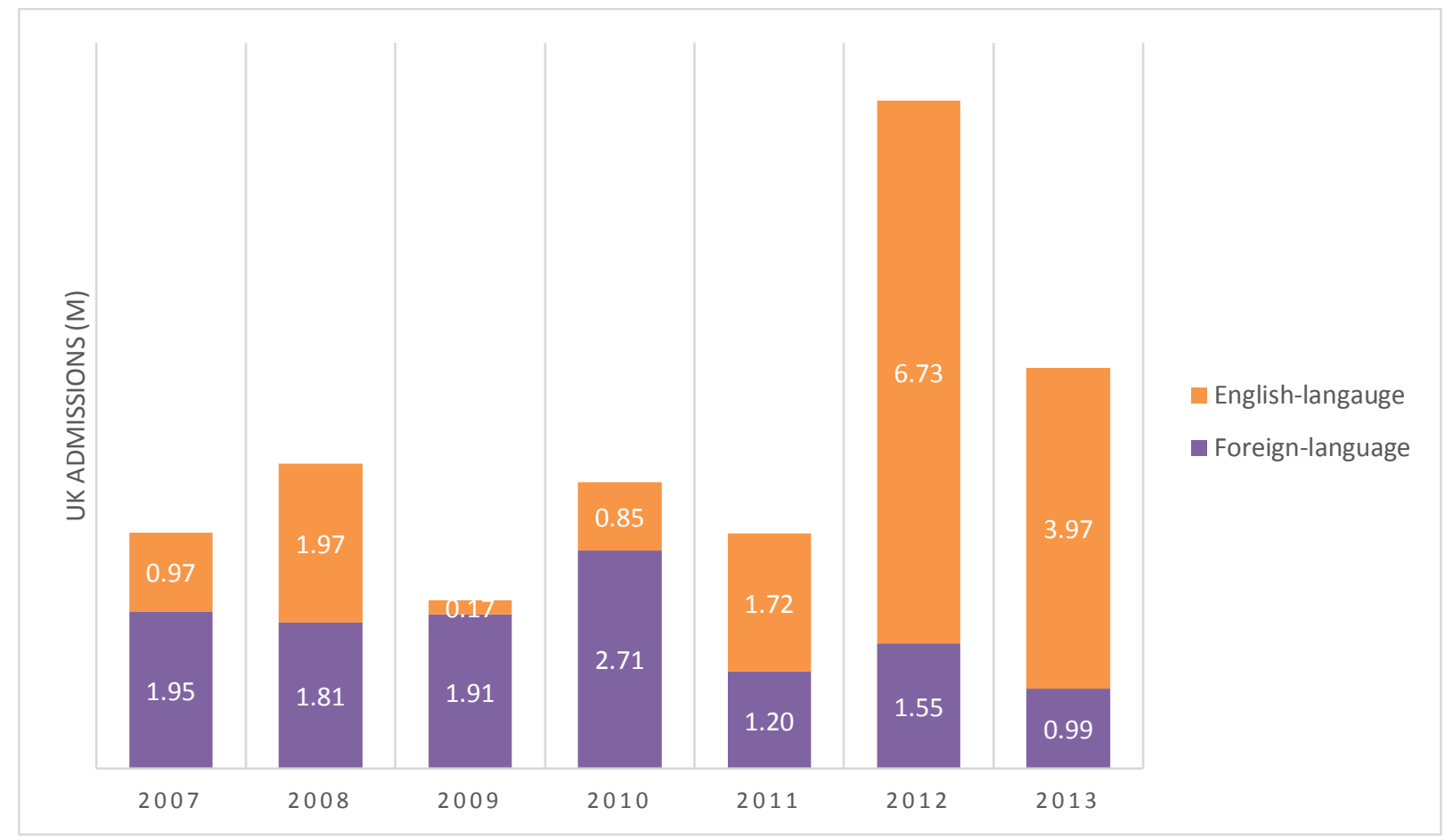

Figure 6. UK admissions for English-language and foreign-language European films, 2007-I3. Source: BFI 2014. 


\begin{tabular}{|c|c|c|c|c|c|c|c|c|c|}
\hline & & \multicolumn{2}{|c|}{ English-language action blockbuster } & \multicolumn{2}{|c|}{ English-language animation } & \multicolumn{2}{|c|}{ English-language dramas } & \multicolumn{2}{|c|}{ Foreign-language films } \\
\hline & & Breakout & $\begin{array}{c}\text { Not } \\
\text { breakout }\end{array}$ & Breakout & $\begin{array}{c}\text { Not } \\
\text { breakout }\end{array}$ & Breakout & $\begin{array}{c}\text { Not } \\
\text { breakout }\end{array}$ & Breakout & $\begin{array}{c}\text { Not } \\
\text { breakout }\end{array}$ \\
\hline \multirow[t]{2}{*}{ Production category } & Co-production & $77.8 \%$ & $50.0 \%$ & $42.9 \%$ & $70.0 \%$ & $80.0 \%$ & $83.3 \%$ & $38.5 \%$ & $46.3 \%$ \\
\hline & Domestic & $22.2 \%$ & $50.0 \%$ & $57.1 \%$ & $30.0 \%$ & $20.0 \%$ & $16.7 \%$ & $61.5 \%$ & $53.7 \%$ \\
\hline Distribution & Hollywood major & $77.8 \%$ & $0.0 \%$ & $14.3 \%$ & $0.0 \%$ & $20.0 \%$ & $7.6 \%$ & $7.7 \% *$ & $0.5 \%$ \\
\hline \multirow[t]{2}{*}{ category } & Major independent & $11.1 \%$ & $50.0 \%$ & $85.7 \%^{*}$ & $35.0 \%$ & $80 \% *$ & $21.2 \%$ & $76.9 \% *$ & $19.6 \%$ \\
\hline & Specialist independent & $11.1 \%$ & $50.0 \%$ & $0.0 \%$ & $65.0 \%$ & $0.0 \%$ & $71.2 \%$ & $15.4 \%$ & $79.8 \% *$ \\
\hline \multirow[t]{3}{*}{ Admissions } & UK & 929,622 & 95,238 & $591,963.3^{*}$ & 38,102 & $965,410.4^{*}$ & 28,144 & $312,502.4^{*}$ & 18,992 \\
\hline & US & $7,625,568$ & 900,744 & $1,118,342$ & 244,417 & $2,491,834.2^{*}$ & 57,995 & $771,972.6^{*}$ & 30,147 \\
\hline & Europe & $5,197,970$ & 763,267 & $4,833,483.6^{*}$ & $1,299,339$ & $6,634,473$ & 512,819 & $7,167,023.6^{*}$ & 838,614 \\
\hline Budget & Budget (\$) & $50,452,856$ & $20,000,000$ & $45,594,480$ & $23,401,245$ & $45,400,000^{*}$ & $16,005,865$ & $12,193,051$ & $9,890,957$ \\
\hline \multirow[t]{2}{*}{ Distribution support } & MEDIA $(€)$ & - & - & - & 7,856 & - & 19,512 & 12,520 & 15,755 \\
\hline & $\mathrm{BFI}(€)$ & - & - & - & 20,508 & - & 9,924 & $120972.2^{*}$ & 11,012 \\
\hline \multirow[t]{4}{*}{ Release strategy } & Rank & 3.1 & 7 & 4.6 & $20.3^{*}$ & 4.4 & $21.4^{*}$ & 9.6 & $25.9 *$ \\
\hline & Open wk/end & 372.1 & 169 & $401.6^{*}$ & 68.5 & $272.4^{*}$ & 51.3 & $76.6^{*}$ & 17.2 \\
\hline & WRP & 374 & 169.5 & $422.1^{*}$ & 75.4 & 343.8 & 52.5 & $104.6^{*}$ & 19.5 \\
\hline & Weeks & 7.1 & 2.5 & 14.4 & 13.6 & 9.4 & 6.3 & $16.7^{*}$ & 6.5 \\
\hline \multirow[t]{2}{*}{ Audience rating } & IMDb & 6.2 & 6.4 & 6.2 & 6.3 & 7.1 & 6.7 & $7.7^{*}$ & 6.8 \\
\hline & Rotten Tomatoes & 54.8 & 74 & 42.3 & $63.1^{*}$ & 68.8 & 61.2 & $76.7^{*}$ & 65.2 \\
\hline \multirow[t]{2}{*}{ Critics rating } & $\mathrm{IMDb}$ & 40 & $54.5^{*}$ & 39 & 64.3 & 61.8 & 58.6 & 73.4 & 69.5 \\
\hline & Rotten Tomatoes & 36.6 & 75 & 32 & 58 & 66.6 & 62.1 & 80.3 & 78.2 \\
\hline \multirow[t]{2}{*}{ Awards } & Awards & 1 & 3.5 & 0.7 & 2.9 & $37.4^{*}$ & 5.2 & $22.1^{*}$ & 5.9 \\
\hline & Nominations & 2.7 & 7 & 2.3 & 6.3 & $48.8^{*}$ & 6.1 & $23.3^{*}$ & 7.8 \\
\hline
\end{tabular}

Table 7. Production, distribution and box office profile of European films by language/genre.

(*indicates significant differences from the mean at the $\mathrm{p}=0.05$ level). Sources: LUMIERE / MEDIA /

BFI / Rotten Tomatoes / Box Office Mojo. 


\begin{tabular}{|c|c|c|c|c|c|c|c|c|}
\hline Baits to attendance & $\begin{array}{l}\text { The Lives of } \\
\text { Others }\end{array}$ & $\begin{array}{c}\text { Coco } \\
\text { Before } \\
\text { Chanel }\end{array}$ & $\begin{array}{l}\text { Let the } \\
\text { Right One } \\
\text { In }\end{array}$ & Tell No One & $\begin{array}{l}\text { The Girl } \\
\text { with the } \\
\text { Dragon } \\
\text { Tattoo }\end{array}$ & $\begin{array}{l}\text { Broken } \\
\text { Embraces }\end{array}$ & $\begin{array}{l}\text { The Skin I } \\
\text { Live In }\end{array}$ & Average \\
\hline The story appealed to me & $52 \%$ & $50 \%$ & $46 \%$ & $41 \% *$ & $28 \%$ & $17 \%$ & $27 \%$ & $37 \% *$ \\
\hline Genre / type of film & $42 \%$ & $26 \%$ & $36 \%$ & $35 \%$ & $18 \%$ & $28 \%$ & $31 \%$ & $31 \%$ \\
\hline Reviews & $56 \% *$ & $12 \%$ & $56 \% *$ & $31 \%$ & $24 \%$ & $0 \%$ & $28 \%$ & $30 \%$ \\
\hline Director & $0 \%$ & $2 \%$ & $0 \%$ & $6 \%$ & $0 \%$ & $74 \% *$ & $74 \% *$ & $22 \%$ \\
\hline Star & $0 \%$ & $32 \%$ & $0 \%$ & $7 \%$ & $0 \%$ & $49 \%$ & $36 \%$ & $18 \%$ \\
\hline Asked by friend / partner & $0 \%$ & $10 \%$ & $32 \%$ & $11 \%$ & $17 \%$ & $21 \%$ & $20 \%$ & $16 \%$ \\
\hline Advertising / poster & $14 \%$ & $14 \%$ & $13 \%$ & $18 \%$ & $10 \%$ & $11 \%$ & $10 \%$ & $13 \%$ \\
\hline $\begin{array}{l}\text { Subject / events of the } \\
\text { film }\end{array}$ & $0 \%$ & $53 \% *$ & $0 \%$ & $0 \%$ & $0 \%$ & $0 \%$ & $14 \%$ & $8 \%$ \\
\hline $\begin{array}{l}\text { Source material (e.g. } \\
\text { book) }\end{array}$ & $0 \%$ & $0 \%$ & $0 \%$ & $7 \%$ & $43 \% *$ & $0 \%$ & $0 \%$ & $8 \%$ \\
\hline Trailer & $21 \%$ & $0 \%$ & $0 \%$ & $0 \%$ & $9 \%$ & $14 \%$ & $0 \%$ & $7 \%$ \\
\hline Award & $28 \%$ & $0 \%$ & $0 \%$ & $0 \%$ & $0 \%$ & $0 \%$ & $8 \%$ & $5 \%$ \\
\hline Friends talking about it & $0 \%$ & $9 \%$ & $0 \%$ & $5 \%$ & $16 \%$ & $0 \%$ & $29 \%$ & $5 \%$ \\
\hline Nationality of film & $0 \%$ & $0 \%$ & $0 \%$ & $5 \%$ & $0 \%$ & $0 \%$ & $0 \%$ & $4 \%$ \\
\hline Cast members & $0 \%$ & $3 \%$ & $0 \%$ & $6 \%$ & $0 \%$ & $0 \%$ & $12 \%$ & $3 \%$ \\
\hline Shown at festival & $0 \%$ & $0 \%$ & $0 \%$ & $0 \%$ & $0 \%$ & $0 \%$ & $0 \%$ & $0 \%$ \\
\hline
\end{tabular}

Table 8. Key 'baits to attendance' for 'breakout' foreign-language European films. (*indicates highest ranked bait). Sources: UKFC/BFI 2007-I3. 